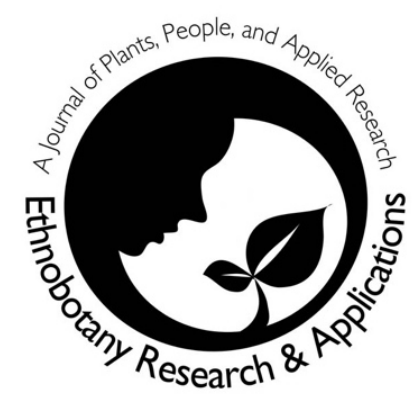

\title{
An ethnobotanical study of plants used for the treatment of malaria in Budondo sub-county, Eastern Uganda
}

\author{
Geoffrey M. Malinga, Kalori Baana, Karlmax Rutaro, \\ Francis Atube, Robert Opoke, Hector Opika-Opoka, \\ Christine Oryema
}

\section{Research}

\begin{abstract}
Background: Malaria is a leading cause of morbidity and mortality in most developing countries, and in Uganda over $95 \%$ of the country is endemic with malaria. Given the increasing widespread resistance to current drugs, the use of herbal medicines is seen as a sustainable solution to malaria treatment. This study documented medicinal plants that are traditionally used for the treatment of malaria in Budondo sub-county, Eastern Uganda.
\end{abstract}

Methods: The ethnobotanical survey was conducted between December 2017 to January 2018. A total of 273 household members were interviewed on knowledge and use of anti-malarial plants, using semistructured questionnaires administered in five parishes of Budondo sub-county. Voucher specimen of each plant species were preserved at the Makerere University herbarium, Uganda.

Results: Overall, $97.5 \%$ of the respondents had knowledge regarding the plants used to treat malaria. A chi-square analysis shows a significant association between respondents' knowledge regarding antimalarial plants and gender ( $p$-value $=0.008)$ and occupation ( $p$-value $=0.025)$ but not with age ( $p$-value $=0.379$ ), educational status ( $p$-value $=0.066$ ), average monthly income ( $p$-value $=0.419)$, and religious affiliation ( $p$-value $=0.064)$ of respondents. A total of 37 plant species, belonging to 25 plant families were used to treat malaria. The most cited plant was Vernonia amygdalina Delile (64.8\%), followed by Aloe vera (L.) Burm.f. (41.9\%), Callistemon citrinus (Curt.) Stapf (29.3\%), Mormodica feotida Schumach (22.0\%), Cyphostemma adenocaule (A. Rich) wild \& Drumm. (16.1\%) and Eucalyptus globulus Labill. (15.4\%). Among the plant parts, stem bark $(99.6 \%)$ and leaves $(90.8 \%)$ were the most frequently used. The habits of the plants encountered were shrub, tree, herb, rhizomes and climber. The commonest modes of preparation included boiling in water, squeezing fresh leaves, crushing and pounding, and chewing. Oral route/drinking was the most common mode of administration, followed by steam inhaling of vapours from the aqueous extracts and skin bathing.

Conclusion: The present study shows that the people living in Budondo sub-county traditionally use diverse flora to treat malaria. Further investigations are required to evaluate the potential toxicological effects and to isolate the active components of the reported plants whose antimalarial activities have not been investigated which could be developed into effective, safe and affordable anti-malarial medicines in the future.

Correspondence
Geoffrey M. Malinga ${ }^{* 1,2}$, Kalori Baana ${ }^{1}$, Karlmax
Rutaro ${ }^{2}$, Francis Atube ${ }^{3}$, Robert Opoke ${ }^{1}$, Hector
Opika-Opoka ${ }^{1}$, Christine Oryema ${ }^{4}$

${ }^{1}$ Department of Biology, Faculty of Science, Gulu
University, P.O. Box 166, Gulu.
2 Department of Environmental \& Biological
Sciences, University of Eastern Finland, P.O. Box
111,80101 Joensuu, Finland
3 Department of Science Education Agriculture,
Faculty of Education and Humanities, Gulu
University, P.O. Box 166, Gulu
4 Department of Biology, Muni University, P.O.Box
725, Arua
*Corresponding Author:
malingageoffrey@yahoo.com
Ethnobotany Research \& Applications
19:04 (2020)


Key words: Anti-malarial plants; Ethnobotanical knowledge; Malaria; Medicinal plants; Traditional medicine; Uganda

\section{Background}

Malaria is one of the key causes of ill health, deaths and poverty in most of developing countries. In 2016 , the world experienced 216 million malaria cases and an estimated 445,000 deaths from malaria was reported (WHO 2017). Ninety percent of these deaths occurred in sub-Saharan Africa, where nearly all malaria is caused by Plasmodium falciparum. Pregnant women and children below five years with lowered immunity are the most affected by the disease (Stangeland et al. 2011, WHO 2016). Uganda ranks $6^{\text {th }}$ among African countries with high clinically diagnosed malaria related mortality and morbidity rates, accounting for approximately 30 $50 \%$ of outpatient visits at health facilities, $15-20 \%$ of all hospital admissions, $9-14 \%$ of hospital deaths, according to the health sector strategic plan (Uganda Ministry of Health 2005). Despite recent key interventions in malaria control like supply of insecticide treated mosquito bed nets and intensified treatment of cases, the disease remains a major public health problem and a leading cause of outpatient visits, admissions and death in the country (Uganda Health Sector Strategic and Investment Development Plan 2010/11-2014/15). Furthermore, the increasing widespread development of resistance of malarial parasites to standardized phytomedicines poses a major threat in the fight against malaria (Mukungu et al. 2016), necessitating continuous search for new antimalarial drugs.

Current antimalarial drugs are derived from plants (e.g., Artemisinin from Artemisia annua L., family Asteraceae). In several African countries including Uganda, there is a long tradition of treating disease with medicinal plants. This practice is still common in most rural parts particularly in areas where the health centres are poorly equipped both with personnel and medicines and lack the necessary infrastructure and resources to manage and control malaria (WHO 2003). This knowledge is often passed by word of mouth from generation to generation. Several plant species are used to treat malaria in Uganda. For example, Tabuti et al. (2003) reported over 20 species in Bulamogi County, Eastern Uganda for treatment of malaria and malaria-related ailments. Kakudidi et al. (2000) and Oryem-Origa et al. (2003) reported Vernonia amyygadalina Delile and Senna didymobotrya (Fresen) Irwin and Barney as two of the most common species used in south western and central Uganda. In Shinile district, Ethiopia, Mesfin et al. (2012) recorded 27 antimalarial plants and Azadirachta indica and Tamarindus indica were the most commonly reported plants. However, up until now there has been no documentation of the use of medicinal plants for treatment of malaria in Budondo sub-county. The aim of the present study was to identify and document the plants that are commonly used by the indigenous people of Budondo subcounty in the treatment of malaria infection.

\section{Materials and methods \\ Study area}

The ethnobotanical survey was carried out in Budondo sub-county located along the bank of river Nile in Jinja district, Uganda, approximately $92 \mathrm{~km}$ by road, north-east of the capital city, Kampala. The area has five parishes, Nawangoma, Buwagi, Ivanumba, Namizi and Kibibi and an estimated 10,084 households (Uganda Bureau of Statistics 2014).

The area is richly endowed with diverse flora, and the traditional healers are reported to be many. The rainfall pattern is bimodal (range: 1,250 to $1,500 \mathrm{~mm}$ per annum) with a dry season from November to February and two short rains from April to May and from September to October (Tabuti \& Mugula 2007). The majority of people in Budondo are poor (Jinja District Development Plan 2015/2016-2019/2020), with very limited health facilities (the sub county has only one health unit, Budondo health centre IV), and there are high malaria incidences, with 7,815 cases (41\%) reported in 2016 ( $\mathrm{MOH} 2016)$. Furthermore, the sub-county has several wetlands, sugar cane plantations and streams which serve as breeding and hiding places for mosquitoes.

\section{Ethnobotanical survey}

Ethnobotanical data on the use of medicinal plants for treatment of malaria was collected between December 2017 and January 2018. Data was collected through a survey by administering semistructured interviews to randomly selected household representatives (i.e., either the household head, spouse or any adult child above 15 years). Interviews were conducted in Lusoga, the principal language spoken in the area. A total of 273 respondents (125 men and 148 women) above 15 years were sampled in the five parishes (Table 1). Data collected included biodata of the respondents, local name of plant species used to treat malaria, plant parts used, habit, mode of remedy preparation and administration, including dosage of the claimed medicinal plants. Prior to conducting the study, permission from the chairpersons of area local councils were obtained and the study was approved by the Gulu University Research and Ethics committee (GUREC-022-19). Written informed consent or assent was sought from each respondent before the onset of interview. The researcher explained to each respondent the objectives of the 
study. Voucher specimens of the reported antimalarial plants were identified by a taxonomist, Rwamburindore P., labeled and deposited in the Herbarium of Makerere University, Uganda. The correctness of the species and family names were checked using the online flora of Tropical Africa database (http://www.tropicos.org, accessed 10/06/2018) and APG IV, (2016), respectively.

\section{Data analysis}

Ethnobotanical data were analyzed using descriptive statistics such as frequencies and percentages. The association between respondents' knowledge with their gender, age, educational status, occupation, religion and income level per month was tested with chi-square analysis (Sokal 1995). All data were analyzed using SPSS, version 23 at a $95 \%$ confidence interval $(P=0.05)$.

\section{Results}

Socio-economic characteristics of respondents The profile of the 273 respondents interviewed in this study is presented in Table 1. $125(45.8 \%)$ of the respondents interviewed were men and $148(54.2 \%)$ were women. The majority (45.8\%) were between 26 to 35 years old. Most of the respondents $(65.9 \%)$ had basic primary school level of education. The majority $(79.5 \%)$ of respondents were peasant farmers and only $21(7.7 \%)$ of the interviewed respondents were formally employed. Most of the respondents earned below Uganda Shilling (UGX) 100,000 (approximately 30 US dollars) per month and the majority belonged to the mainstream religions and were mostly Catholics (32.2\%), Anglican (28.2\%), Pentecostals (16.8\%) and Muslims (16.1\%). Overall, $96.7 \%(264 / 273)$ of respondents had knowledge about antimalarial plants (Table 1 ).

\section{Traditional knowledge on antimalarial plants}

A chi-square analysis shows significant associations in the knowledge of the antimalarial plants and gender $\left(X^{2}=7.0, \quad d f=1, \quad P\right.$-value=0.008), and occupation $\left(X^{2}=9.3, \mathrm{df}=3, P=0.025\right)$. The women were more knowledgeable than the men (Table 2). The peasant farmers were more knowledgeable than the others. However, there was no significant association with education status $\left(\mathrm{X}^{2}=8.8, \mathrm{df}=4, P=\right.$ 0.066), religion $\left(X^{2}=10.4, \mathrm{df}=5, P<0.064\right)$ and income status of respondents $\left(X^{2}=6.0, d f=6\right.$, $P=0.419$ ) (Table 2).

Traditionally used antimalarial medicinal plants A total of 37 plant species both cultivated and wild belonging to 25 different families were reported to be used in treatment and cure of malaria infection in Budondo sub county (Table 3). The family Asteraceae was the most commonly represented with five species, followed by Myrtaceae (four species), Solanaceae (three species), and the families Bignoniaceae, Verbenaceae and Rutaceae were represented with two species each. The rest of the families (19) had one species each. Most of plants were reported to be native to Budondo with exception of Azadirachta indica Juss, Callistemon citrinus (Curt.) Stapf and Cannabis sativa L. which were introduced from other areas. The most commonly used plant was Vernonia amygdalina (mentioned by $64.8 \%$ of the respondents). Other commonly used plants included Aloe vera L. (41.8\%), Callistemon citrinus (Curt.) Stapf (29.3\%), Mormodica feotida Schumach (22.0\%), Cyphostemma adenocaule (A. Rich) Wild \& Drumm. (16.1\%), Eucalyptus globulus L. (15.4\%) (Table 3). Herbs constituted the highest number of medicinal plants (16 species), followed by trees (14 species) and shrubs (7 species) (Table 3 ).

Table 1. Socio-demographic characteristics of the respondents $(n=273)$

\begin{tabular}{|c|c|c|}
\hline Characteristics & Frequency & Percent \\
\hline \multicolumn{3}{|l|}{ Gender } \\
\hline Male & 125 & 45.8 \\
\hline Female & 148 & 54.2 \\
\hline \multicolumn{3}{|l|}{$\begin{array}{l}\text { Age of respondents } \\
\text { (years) }\end{array}$} \\
\hline $15-25$ & 22 & 8.1 \\
\hline 26-35 & 125 & 45.8 \\
\hline $36-45$ & 70 & 26.6 \\
\hline $46-55$ & 35 & 12.5 \\
\hline $56-65$ & 14 & 5.1 \\
\hline Above 66 & 7 & 2.6 \\
\hline \multicolumn{3}{|l|}{ Educational status } \\
\hline None & 16 & 5.9 \\
\hline Primary & 180 & 65.9 \\
\hline Ordinary secondary & 33 & 12.1 \\
\hline Advanced secondary & 21 & 7.7 \\
\hline Post-secondary & 23 & 8.4 \\
\hline \multicolumn{3}{|l|}{ Occupation } \\
\hline Peasant (small farmers) & 217 & 79.5 \\
\hline Civil servant & 21 & 7.7 \\
\hline Trader/self-employed & 12 & 4.4 \\
\hline Student & 23 & 8.4 \\
\hline \multicolumn{3}{|l|}{ Religion } \\
\hline Catholic & 88 & 32.2 \\
\hline Anglican & 77 & 28.2 \\
\hline Muslim & 46 & 16.8 \\
\hline Pentecostal & 44 & 16.1 \\
\hline Traditionalist & 13 & 4.8 \\
\hline Others & 5 & 1.8 \\
\hline \multicolumn{3}{|l|}{ Monthly income status } \\
\hline Less than 10,000 & 28 & 10.3 \\
\hline $10,000-100,000$ & 97 & 35.5 \\
\hline $101,000-200,000$ & 70 & 25.6 \\
\hline $201,000-300,000$ & 45 & 16.5 \\
\hline $301,000-400,000$ & 12 & 4.4 \\
\hline $401,000-500,000$ & 10 & 3.7 \\
\hline Above 500,000 & 11 & 4.0 \\
\hline \multicolumn{3}{|l|}{$\begin{array}{l}\text { Knowledge on anti- } \\
\text { malarial plants }\end{array}$} \\
\hline Yes & 264 & 96.7 \\
\hline No & 9 & 3.3 \\
\hline
\end{tabular}


Table 2. Knowledge on antimalarial plants in relation with age, gender, educational status, religion, occupation and income status of the respondents

\begin{tabular}{|c|c|c|c|c|c|}
\hline \multirow[t]{2}{*}{ Characteristics } & \multirow[t]{2}{*}{$\begin{array}{l}\text { Total number } \\
\text { of respondents }\end{array}$} & \multicolumn{2}{|c|}{$\begin{array}{l}\text { Knowledge on antimalarial } \\
\text { plants }\end{array}$} & \multirow[t]{2}{*}{$x^{2}$} & \multirow[t]{2}{*}{ P-value } \\
\hline & & No & Yes & & \\
\hline \multicolumn{6}{|l|}{ Gender } \\
\hline Male & 125 & 8 & 117 & \multirow{2}{*}{$x^{2}=7.0, d f=1$} & \multirow[t]{2}{*}{$P=0.008$} \\
\hline Female & 148 & 1 & 147 & & \\
\hline \multicolumn{6}{|l|}{ Age (years) } \\
\hline $15-25$ & 22 & 1 & 21 & \multirow{6}{*}{$x^{2}=5.3, d f=5$} & \multirow[t]{6}{*}{$P=0.379$} \\
\hline $26-35$ & 125 & 7 & 118 & & \\
\hline $36-45$ & 70 & 0 & 70 & & \\
\hline $46-55$ & 35 & 1 & 34 & & \\
\hline $56-65$ & 14 & 0 & 14 & & \\
\hline Above 66 & 7 & 0 & 7 & & \\
\hline \multicolumn{6}{|l|}{ Educational status } \\
\hline Illiterate & 16 & 0 & 16 & \multirow{5}{*}{$x^{2}=8.8, d f=5$} & \multirow{5}{*}{$P=0.066$} \\
\hline Primary & 180 & 5 & 175 & & \\
\hline Ordinary secondary & 33 & 0 & 33 & & \\
\hline Advanced secondary & 21 & 1 & 20 & & \\
\hline Post-secondary & 23 & 3 & 20 & & \\
\hline \multicolumn{6}{|l|}{ Occupation } \\
\hline Peasant (small farmers) & 217 & 6 & 211 & \multirow{2}{*}{$x^{2}=9.3, d f=3$} & \multirow[t]{2}{*}{$P=0.025$} \\
\hline Trader/self-employed & 23 & 0 & 23 & & \\
\hline \multicolumn{6}{|l|}{ Reliqion } \\
\hline Catholic & 88 & 1 & 87 & \multirow[t]{6}{*}{$x^{2}=10.4, d f=5$} & \multirow[t]{6}{*}{$P=0.064$} \\
\hline Anglican & 77 & 2 & 75 & & \\
\hline Muslim & 44 & 1 & 43 & & \\
\hline Pentecostal & 46 & 5 & 41 & & \\
\hline Traditionalist & 13 & 0 & 13 & & \\
\hline Others & 5 & 0 & 5 & & \\
\hline \multicolumn{6}{|l|}{$\begin{array}{l}\text { Monthly income status } \\
\text { (UG X) }\end{array}$} \\
\hline Less than 10,000 & 28 & 2 & 26 & \multirow[t]{5}{*}{$x^{2}=6.0, d f=6$} & \multirow[t]{5}{*}{$P=0.419$} \\
\hline $101,000-200,000$ & 70 & 1 & 69 & & \\
\hline $201,000-300,000$ & 45 & 3 & 42 & & \\
\hline $301,000-400,000$ & 12 & 0 & 12 & & \\
\hline $401,000-500,000$ & 10 & 0 & 10 & & \\
\hline
\end{tabular}

Plant parts used, mode of preparation, dosage and administration of remedies

Stem was the most commonly used plant part in the preparation of remedy against malaria constituting $99.6 \%$ of the preparations, followed by leaf $(90.6 \%)$, fruits $(11.4 \%)$, seeds $(5.1 \%)$, flowers $(2.6 \%)$ and the least was whole plant $(0.7 \%)$. Majority used fresh parts except the seeds that were dried first. The principal modes of preparation included boiling in water, squeezing fresh leaves, crushing and pounding, and chewing. Cold or hot water was the main solvent for herbal preparations. In the majority of cases, the respondents mostly used single plant species in remedy preparations. However, plants like Mangifera indica L, Persea americana Mill., Carica papaya L., Coffea canephora Froehner and Markhamia lutea (Benth.) K.Schum. were reported to be prepared as mixtures. The majority of the antimalarial plant remedies (33 species) were taken orally. Most of the plants administered through oral route were reported to have a bitter taste. The plants were used until the patient's condition had improved and there were variations in unit of measurements, dosages, frequency and appropriate times for the administration of remedies. Dosages were estimated using different units such as cup and teaspoon and children were often given half of the dosage of adults. Most of the herbal remedies prescribed were taken twice or three times a day.

\section{Discussion}

Our results revealed that 37 plant species belonging to 25 different families are commonly used for treatment of malaria in Budondo sub county, with Asteraceae and Myrtaceae being the most predominant plant families in terms of number of species. The use of Myrtaceae and Asteraceae in the treatment of malaria has been reported in several earlier previous studies, such as in Cameroon (Simbo 2010), Uganda (Namukobe et al. 2011) and in Nigeria (Olorunnisola et al. 2013). Different 
species of Asteraceae are reported to have pharmacological properties, for example Olorunnisola et al. (2013) reported three plant species (Chromolaena odorata L; Vernonia amygdalina Delile and Ageratum conyzoides L.) that are used for treating malaria in Southwest Nigeria. Most of the plants cited in the current study have been reported by different communities elsewhere in Uganda and other countries in Africa for management of malaria (Tabuti 2008, Ssegawa \& Kasenene 2007, Stangeland et al. 2011, Mesfin et al. 2012) suggesting that these species may be effective in the treatment of malaria. For example, $V$. armygdalina, Aloe sp, and $A$. indica were reported by Stangeland et al. (2011) to be used for treating malaria in western Uganda whereas Ssegawa and Kasenene (2007) reported $A$. indica and Citrus limon (L.) Osbeck (Rutaceae) for treatment of malaria in southern Uganda. In Ethiopia, Mesfin et al. (2012) mentioned Aloe sp, A. indica and Tamarindus indica to be used in treatment of Malaria in Shinile district, Somali region of Ethiopia. However, the number of plant species reported (37 plant species) are higher than those reported (20 species) in the mostly swampy sub-county of Cegere in northern Uganda (Anywar et al. 2016), although lower than those reported (48 species) in Nyakayojo sub-county in western Uganda (Stangeland et al. 2011).

Overall, the results of the present study clearly indicated that the people of Budondo in Uganda were knowledgeable (97.8\% of respondents) concerning antimalarial plants. However, there was no significant difference observed between knowledge of plants used to treat malaria and the educational status, religion, age and average income status of respondents. This suggests that the plants are well known by the community irrespective of educational status, age, religious affiliation and income status. Nevertheless, the knowledge of antimalarials was significantly associated with gender ( $p$-value = 0.008 ) and occupation ( $p$-value $=0.025$ ) of the respondent. Women were more knowledgeable about the plants than men because women are more responsible for the health care of the family members, especially children than men (Oreagba et al. 2004). Besides, malaria majorly affects pregnant women and children below five years old (Stangeland et al. 2011), and thus women easily obtain this information to curb down the disease. The present result is consistent with the findings of Tabuti et al. (2003) in Badiope county, Eastern Uganda.

Furthermore, our results also indicated that the people of Budondo mostly use stem (99.9\%) and leaves (90.6\%). This agrees with the work of Anywar et al. (2016) on medicinal plants of Cegere, in northern Uganda and with the works of Pierre et al.
(2011) in Cameroon, where they showed that leaves and stem constituted the majority of the plant parts used. Leaves and stem are the plant parts most commonly used by traditional medicine practitioners in many African countries (Olorunnisola et al. 2013, Mukungu et al. 2016). The routine use of leaves could be a result of the fact that leaves are the sites for synthesis and storage of the majority of plant secondary metabolites or bioactive compounds which are presumed to have anti-plasmodium actions (Pierre et al. 2011). Besides, regular harvest of leaves poses minimal threat to the survival of individual plants and this could be a conservation strategy of the plants by the communities. However, frequent usage of stem for herbal preparations can be risky for the survival of a plant species. Therefore, to ensure sustainable utilization of medicinal plant resources, application of proper harvesting strategies and conservation measures is necessary.

Most of the plants used for treating malaria were prepared by squeezing juice out of the fresh leaves and boiling in water (Table 2) which is in agreement with previous study by Olorunnisola et al. (2013) in south-west Nigeria and by Mukungu et al. (2016) in Kenya. Also, water was mostly used as solvent in making herbal preparations as earlier reported by Kamatenesi et al. (2011). The herbal remedies were primarily administered through oral route, but rarely through intranasal and whole-body steam baths. Fresh parts were also eaten and chewed directly upon collection or after initial pounding. These findings are in agreement with observations in other studies elsewhere (Kamatenesi et al. 2011, Olorunnisola et al. 2013, Mukungu et al. 2016). The oral route is suited for systemic treatment of malaria because the disease is caused by intracellular haemo-parasites and its treatment require taking sufficient circulating concentration of suitable antiprotozoan compounds from herbal medication. This allows comparatively rapid absorption and distribution of bioactive compounds from the plants, allowing the delivery of adequate curative power (Teklay et al. 2013).

\section{Conclusions}

The present study shows that the people living in Budondo have a rich knowledge on anti-malarial plants which could be exploited in the development of new anti-malarial drugs. However, future research on in-vitro anti-plasmodial efficacy and toxicological studies of the plants are needed to generate confidence in their use. Also, it is needed to identify and isolate bioactive compounds in these plants that could be developed into new effective and affordable standardized phytomedicines. 
Table 3. Plants used for the management of malaria among the Basoga community in Budondo sub county, Uganda

\begin{tabular}{|c|c|c|c|c|c|c|c|c|c|}
\hline $\begin{array}{l}\text { Family and scientific } \\
\text { name }\end{array}$ & Lusoga name & $\begin{array}{l}\text { Part } \\
\text { used }\end{array}$ & Life form & $\begin{array}{l}\text { Cultivated } \\
\text { / wild }\end{array}$ & $\begin{array}{l}\text { Mode of preparation } \\
\text { and administration }\end{array}$ & $\begin{array}{l}\text { Frequenc } \\
\text { y of } \\
\text { mention }\end{array}$ & Percent & $\begin{array}{l}\text { Reported antimalarial or anti- } \\
\text { plasmodial activity (if known) }\end{array}$ & $\begin{array}{l}\text { Active chemical } \\
\text { constituent }\end{array}$ \\
\hline \multicolumn{10}{|l|}{ ALLIACEAE } \\
\hline $\begin{array}{l}\text { Allium sativum } \mathrm{L} \text {. } \\
\text { GMM032 }\end{array}$ & $\begin{array}{l}\text { Katunguluccum } \\
\mathrm{u}\end{array}$ & Leaves & Herb & Cultivated & $\begin{array}{l}\text { Chew the leaves and } \\
\text { swallow }\end{array}$ & 3 & 1.1 & No record & \\
\hline \multicolumn{10}{|l|}{ AMARYLLIDACEAE } \\
\hline $\begin{array}{l}\text { Allium cepa L. } \\
\text { GMM028 }\end{array}$ & Katungulu & $\begin{array}{l}\text { Leaves, } \\
\text { Bulb; } \\
\text { Fruits }\end{array}$ & Herb & Cultivated & $\begin{array}{l}\text { Crush the leaves/bulb, } \\
\text { add water and drink or } \\
\text { just chew the leaves } \\
\text { and swallow }\end{array}$ & 4 & 1.5 & No record & \\
\hline \multicolumn{10}{|l|}{ ANACARDIACEAE } \\
\hline $\begin{array}{l}\text { Mangifera indica L. } \\
\text { GMM014 }\end{array}$ & Muyembe & $\begin{array}{l}\text { Leaves, } \\
\text { Bulb }\end{array}$ & Tree & Cultivated & $\begin{array}{l}\text { Boil leaves or bark for } \\
20 \text { minutes, allow to } \\
\text { cool and drink the } \\
\text { filtrate, three table } \\
\text { spoons three times or } \\
\text { a full cup twice }\end{array}$ & 15 & 5.5 & $\begin{array}{l}\text { Chloroform: methanol }(1: 1) \\
\text { hot water extract inhibited } \\
\text { growth of chloroquine } \\
\text { resistant strain of } P \text {. } \\
\text { falciparum by }>50 \% \text { at } \\
50 \mu \mathrm{g} / \mathrm{ml} \text { (Zirihi et al. } 2005 \text { ) }\end{array}$ & $\begin{array}{l}\text { Phenolics (Barreto } \\
\text { et al. 2008) }\end{array}$ \\
\hline \multicolumn{10}{|l|}{$\begin{array}{l}\text { ARISTOLOCHIACEA } \\
\mathrm{E}\end{array}$} \\
\hline $\begin{array}{l}\text { Aristolochia elegans } \\
\text { Mast. GMM007 }\end{array}$ & Nakasero & $\begin{array}{l}\text { Leaves, } \\
\text { Stems }\end{array}$ & $\begin{array}{l}\text { Herbaceous } \\
\text { climber }\end{array}$ & $\begin{array}{l}\text { Cultivated } \\
\text { / wild }\end{array}$ & $\begin{array}{l}\text { Squeeze, add water } \\
\text { and drink, two table } \\
\text { spoons three times for } \\
\text { adults, or one table } \\
\text { spoon twice (children) }\end{array}$ & 35 & 12.8 & $\begin{array}{l}\text { Inhibited }>50 \text { (Plasmodium } \\
\text { falciparum sensitive strain: } \\
\text { 3D7); undetectable } \\
\text { chloroquine resistant } P \text {. } \\
\text { falciparum, W2 (Muganga et } \\
\text { al. 2010) }\end{array}$ & $\begin{array}{l}\text { Sesquiterpenoids, } \\
\text { diterpenoids, } \\
\text { monoterpenoids, } \\
\text { alkaloids (Wu et al. } \\
\text { 2004, Shi et al. } \\
\text { 2004) }\end{array}$ \\
\hline \multicolumn{10}{|l|}{ ASPHODELACEAE } \\
\hline $\begin{array}{l}\text { Aloe vera (L.) Burm.f. } \\
\text { GMM002 }\end{array}$ & Kikaka/Kigagi & Leaves & Herb & Cultivated & $\begin{array}{l}\text { Boil fresh leaves in } \\
\text { water and drink }\end{array}$ & 114 & 41.8 & $\begin{array}{l}\text { Anti-plasmodial activity with } \\
\text { respect to effective dose } \\
\left(E D_{50}\right) \text { values from crude } \\
\text { aqueous extracts ranged } \\
\text { from } 0.289 \text { to } 1.056 \mu \mathrm{g} / \mathrm{ml} \\
\text { (chloroquine sensitive) } \\
\text { (Kumar et al. } 2017 \text { ) }\end{array}$ & $\begin{array}{l}\text { Anthraquinone,Aloi } \\
\text { n, aloe-emodin } \\
\text { (Kumar et al. 2017) }\end{array}$ \\
\hline \multicolumn{10}{|l|}{ ASTERACEAE } \\
\hline $\begin{array}{l}\text { Vernonia amygdalina } \\
\text { Dellile GMM001 }\end{array}$ & Lubilili & $\begin{array}{l}\text { Leaves, } \\
\text { Stems }\end{array}$ & Shrub & Wild & $\begin{array}{l}\text { Fresh leaves squeezed } \\
\text { and mix with cold water } \\
\text { and drunk (either two } \\
\text { tablespoon, three times } \\
\text { or a quarter of a cup } \\
\text { three times). }\end{array}$ & 177 & 64.8 & $\begin{array}{l}\text { Ethanolic extracts of leaves } \\
\mathrm{IC}_{50} 9.8 \mathrm{mg} / \mathrm{ml} \text { (Omoregie et } \\
\text { al. 2011). }\end{array}$ & $\begin{array}{l}\text { Coumarine; } \\
\text { sesquiterpene } \\
\text { lactones and } \\
\text { steroid glycoside } \\
\text { (Jisaka et al. 1992; } \\
\text { Erasto et al. 2006) }\end{array}$ \\
\hline
\end{tabular}


Ethnobotany Research and Applications

\begin{tabular}{|c|c|c|c|c|c|c|c|c|c|}
\hline $\begin{array}{l}\text { Vernonia lasiopus O. } \\
\text { Hoffm. GMM009 }\end{array}$ & $\begin{array}{l}\text { Lubirizi olutono } \\
\text { Kaluluza }\end{array}$ & Leaves & Shrub & Wild & $\begin{array}{l}\text { Crush a handful of } \\
\text { fresh leaves, mix with } \\
\text { cold water and drink } \\
\text { one table spoon three } \\
\text { times a day for a week. }\end{array}$ & 24 & 8.8 & $\begin{array}{l}\text { Methanol extract of leaves in } \\
\text { hot water IC } 50 \text { values: } 44.3 \\
\mu \mathrm{g} / \mathrm{ml} \text { (chloroquine sensitive, } \\
\text { D6); } 52.4 \mu \mathrm{g} / \mathrm{ml} \text { (Chloroquine } \\
\text { resistant, W2) (Muregi et al. } \\
\text { 2007; Okello \& Kang } \\
\text { 2019).Petroleum ether } \\
\text { extract exhibit anti-malarial } \\
\text { activity against wild strain of } \\
P \text {. plasmodium (IC50 }=43.9 \text { ), } \\
\text { chloroform extract }>50 \text {, } \\
\text { ethanolic extract }>50 \\
\text { (Katuura et al. } 2007 \text { ) }\end{array}$ & $\begin{array}{l}\text { Sesquiterpene } \\
\text { lactones, } \\
\text { polysaccharides } \\
\text { (Koul et al. 2003); } \\
\text { polysaccarides } \\
\text { (Nergard et al. } \\
\text { 2004) }\end{array}$ \\
\hline $\begin{array}{l}\text { Lactuca capensis } \\
\text { Thunb. GMM025 }\end{array}$ & Isseja & Leaves & Herb & Wild & $\begin{array}{l}\text { Boil for } 30 \text { minutes and } \\
\text { drink a half a cup two } \\
\text { times }\end{array}$ & 5 & 1.8 & No record & \\
\hline $\begin{array}{l}\text { Senecio discifolius } \\
\text { Oliv, GMM026 }\end{array}$ & Kakyamusure & Leaves & Herb & Wild & $\begin{array}{l}\text { Vaporization and } \\
\text { intranasal inhaling only } \\
\text { to individuals above } 20 \\
\text { years twice a day. }\end{array}$ & 4 & 1.5 & No record & \\
\hline $\begin{array}{l}\text { Aspilia africana (Pers.) } \\
\text { C. D. Adams GMM036 }\end{array}$ & Makayi & Leaves & Herb & Wild & $\begin{array}{l}\text { Squeeze sap from } \\
\text { either the leaves, and } \\
\text { drink the sap }\end{array}$ & 2 & 0.7 & $\begin{array}{l}\text { Ethyl acetate extract, } \\
\text { inhibitory concentration } \\
\left(\mathrm{IC}_{50}\right) 9.3 \mu \mathrm{g} / \mathrm{ml} \text { against the } \\
\text { chloroquine sensitive (D10) } \\
\text { strain of } P \text {. falciparum and } \\
11.5 \mu \mathrm{g} / \mathrm{ml} \text { against the } \\
\text { chloroquine sensitive }(\mathrm{KI}) \\
\text { strain (Waako et al. 2007). }\end{array}$ & $\begin{array}{l}\text { Saponins, } \\
\text { terpenoids, } \\
\text { alkaloids, resins, } \\
\text { tannins, flavonoids, } \\
\text { sterols (Okoli et al. } \\
\text { 2007) }\end{array}$ \\
\hline \multicolumn{10}{|l|}{ BIGNONIACEAE } \\
\hline $\begin{array}{l}\text { Markhamia lutea } \\
\text { (Benth) K. Schum. } \\
\text { GMM011 }\end{array}$ & Musambya & $\begin{array}{l}\text { Leaves, } \\
\text { Stem } \\
\text { bark }\end{array}$ & Tree & $\begin{array}{l}\text { Wild / } \\
\text { Cultivated }\end{array}$ & $\begin{array}{l}\text { Vaporization and } \\
\text { intranasal inhaling }\end{array}$ & 17 & 6.2 & $\begin{array}{l}\text { Ethyl acetate extract of } \\
\text { leaves in hot water caused } \\
71 \% \text { inhibition of } P \text {. } \\
\text { falciparum at } 10 \mu \mathrm{g} / \mathrm{ml} \\
\text { (Lacroix et al. 2009) }\end{array}$ & $\begin{array}{l}\text { Cycloartane } \\
\text { triterpenoids, } \\
\text { Phenylpropanoid } \\
\text { glycosides (Kernan } \\
\text { et al. 1998; Lacroix } \\
\text { et al. 2009) }\end{array}$ \\
\hline $\begin{array}{l}\text { Spathodea nilotica } \\
\text { Seem. GMM033 }\end{array}$ & Kinalisa & Leaves & Tree & Wild & $\begin{array}{l}\text { Boil for } 20 \text { minutes and } \\
\text { drink the filtrate, a } \\
\text { whole cup two times }\end{array}$ & 2 & 0.7 & $\begin{array}{l}\text { Ethyl acetate extract of stem } \\
\text { bark in water inhibition of } P \text {. } \\
\text { falciparum by } 28.9 \% \text { at } 10 \\
\mu \mathrm{g} / \mathrm{ml} \text { (Lacroix et al. } 2011 \text { ) }\end{array}$ & $\begin{array}{l}\text { Quinone (Lacroix et } \\
\text { al. 2011) }\end{array}$ \\
\hline
\end{tabular}


Ethnobotany Research and Applications

\begin{tabular}{|c|c|c|c|c|c|c|c|c|c|}
\hline \multicolumn{10}{|l|}{ CANNABACEAE } \\
\hline $\begin{array}{l}\text { Cannabis sativa L. } \\
\text { GMM035 }\end{array}$ & Enjaye & Leaves & Herb & Cultivated & $\begin{array}{l}\text { Boil leaves in water for } \\
30 \text { minutes while } \\
\text { covering the container, } \\
\text { allow the victim to } \\
\text { inhale the vapor while } \\
\text { covering the head with } \\
\text { a thick cloth }\end{array}$ & 2 & 0.7 & No record & \\
\hline \multicolumn{10}{|l|}{ CARICACEAE } \\
\hline $\begin{array}{l}\text { Carica papaya L. } \\
\text { GMM021 }\end{array}$ & Mapapali & $\begin{array}{l}\text { Leaves, } \\
\text { Fruit }\end{array}$ & Tree & Cultivated & $\begin{array}{l}\text { Vaporization and } \\
\text { intranasal inhaling or } \\
\text { boil leaves in } \\
\text { water/steam for } 20 \\
\text { minutes, make } \\
\text { decoction and drink; } \\
\text { three tablespoons for } \\
\text { adults above } 16 \text { years }\end{array}$ & 6 & 2.2 & $\begin{array}{l}\text { Ethyl acetate extract of } C \text {. } \\
\text { papaya leaves showed IC } 50 \\
\text { of } 2.96 \text { against } P \text {. } \\
\text { falciparum- chloroquine } \\
\text { sensitive, D10; } 3.98 \\
\text { (Chloroquine resistant, } \\
\text { DD2); Methanol extract of } \\
\text { leaves: } 10.8 \text { (chloroquine } \\
\text { sensitive, D10). (Melariri et } \\
\text { al. } 2011, \text { Teng et al. 2019) }\end{array}$ & $\begin{array}{l}\text { Alkaloids, saponins, } \\
\text { tannins and } \\
\text { glycosides (Melariri } \\
\text { et al. 2011,) }\end{array}$ \\
\hline \multicolumn{10}{|l|}{ FABACEAE } \\
\hline $\begin{array}{l}\text { Senna didymobotrya } \\
\text { (Fresen.) } \\
\text { H.S.Irwin \& Barneby } \\
\text { (GMM029) }\end{array}$ & Muvuvumira & Leaves & Shrub & Wild & $\begin{array}{l}\text { Boil fresh leaves in } \\
\text { water for } 30 \text { minutes } \\
\text { and drink the resulting } \\
\text { filtrate-three table } \\
\text { spoonful for adults and } \\
\text { one tablespoon for } \\
\text { children below } 10 \\
\text { years three times a day }\end{array}$ & 4 & 1.4 & $\begin{array}{l}\text { Methanol extract of leaves in } \\
\text { hot water showed anti- } \\
\text { plasmodial activity }\left(\mathrm{IC}_{50}=100\right. \\
\mathrm{mg} / \mathrm{ml} \text { against the } \\
\text { Chloroquine sensitive strain } \\
\text { of } P \text {. falciparum, K39 } \\
\text { (Muregi et al. 2003) }\end{array}$ & $\begin{array}{l}\text { Quinones } \\
\text { (Alemayehu et al. } \\
\text { 1989) }\end{array}$ \\
\hline \multicolumn{10}{|l|}{ CUCURBITACEAE } \\
\hline $\begin{array}{l}\text { Momordica foetida } \\
\text { Schumach. GMM004 }\end{array}$ & Eibombo & $\begin{array}{l}\text { Leaves, } \\
\text { Stems }\end{array}$ & $\begin{array}{l}\text { Herbaceous } \\
\text { climber }\end{array}$ & Wild & $\begin{array}{l}\text { Squeeze, add water or } \\
\text { infusion and drink or } \\
\text { bath }\end{array}$ & 60 & 22 & $\begin{array}{l}\text { Aqueous extract of shoot in } \\
\text { hot water: } 6.16 \text { (chloroquine } \\
\text { sensitive, NF54); } 0.35 \\
\text { (Chloroquine resistant, } \\
\text { FCR3) (Adia et al. 2016). }\end{array}$ & $\begin{array}{l}\text { Saponins, alkaloids, } \\
\text { cardiac glycosides } \\
\text { (Adia et al. 2016) }\end{array}$ \\
\hline \multicolumn{10}{|l|}{ CUPRESSACEAE } \\
\hline $\begin{array}{l}\text { Cupressus } \\
\text { sempervirens L. } \\
\text { GMM016 }\end{array}$ & Kurismasitri & Leaves & Tree & Cultivated & $\begin{array}{l}\text { Either burn three days } \\
\text { old harvested leaves to } \\
\text { produce the smoke } \\
\text { and inhale the smoke } \\
\text { or boil the leaves for } 30 \\
\text { minutes covering the } \\
\text { container and inhale } \\
\text { the resulting vapor }\end{array}$ & 9 & 3.3 & No record & \\
\hline
\end{tabular}


Ethnobotany Research and Applications

\begin{tabular}{|c|c|c|c|c|c|c|c|c|c|}
\hline \multicolumn{10}{|l|}{ EUPHORBIACEAE } \\
\hline $\begin{array}{l}\text { Manihot esculenta } \\
\text { Crantz GMM015 }\end{array}$ & Mowoga & Leaves & Shrub & Cultivated & $\begin{array}{l}\text { Boil leaves in a } \\
\text { saucepan for } 30 \\
\text { minutes, remove the } \\
\text { cover and allow the } \\
\text { person to inhale the } \\
\text { vapor twice a day (for } \\
\text { individuals above } 20 \\
\text { years) }\end{array}$ & 9 & 3.3 & No record & \\
\hline \multicolumn{10}{|l|}{ LAMIACEAE } \\
\hline $\begin{array}{l}\text { Ocimum basilicum L. } \\
\text { GMM019 }\end{array}$ & Kakubansiri & $\begin{array}{l}\text { Leaves, } \\
\text { Whole } \\
\text { plant }\end{array}$ & Herb & Wild & $\begin{array}{l}\text { Vaporization and } \\
\text { intranasal inhaling at } \\
\text { least twice a day }\end{array}$ & 8 & 2.9 & $\begin{array}{l}\text { Methanolic leaf extracts } \\
\text { showed anti-plasmodial } \\
\text { activity against chloroquine } \\
\text { sensitive, D6 }\left(I_{50}=16.4\right) \\
\text { (Muthaura et al. } 2015) \text {, and } \\
\text { against chloroquine } \\
\text { sensitive, } C Q-s\left(I_{50}=68.14\right. \\
\mu g / m l) ; \text { and chloroquine } \\
\text { resistant, CQ-r (IC } 50=67.27 \\
\mu g / m l) \text { (Murugan et al. } \\
2015) \text {. }\end{array}$ & $\begin{array}{l}\text { Quinones } \\
\text { (Alemayehu et al. } \\
\text { 1989) }\end{array}$ \\
\hline \multicolumn{10}{|l|}{ LAURACEAE } \\
\hline $\begin{array}{l}\text { Persea americana Mill } \\
\text { GMM012 }\end{array}$ & Fakedo & $\begin{array}{l}\text { Leaves, } \\
\text { Bark, } \\
\text { Seeds }\end{array}$ & Tree & Cultivated & $\begin{array}{l}\text { Vaporization and } \\
\text { intranasal inhaling }\end{array}$ & 16 & 5.9 & $\begin{array}{l}\text { Ethanol extract of leaves in } \\
\text { hot water effective against } \\
\text { chloroquine sensitive, 3D7 } \\
\left.\text { (IC } \text { C }_{50}=10.15 \mu \mathrm{g} / \mathrm{ml}\right) \\
\text { chloroquine sensitive, CQ-s } \\
\left(\mathrm{IC}_{50}=68.14 \mu \mathrm{g} / \mathrm{ml} \text { ) and }\right. \\
\text { chloroquine resistant, W2 } \\
\left(\mathrm{IC}_{50}=44.94 \mu \mathrm{g} / \mathrm{ml}\right) \\
\text { (Komlaga et al. } 2016)\end{array}$ & $\begin{array}{l}\text { Phenolics (Canini et } \\
\text { al. 2007, Komlaga } \\
\text { et al. 2016) }\end{array}$ \\
\hline \multicolumn{10}{|l|}{ MELIACEAE } \\
\hline $\begin{array}{l}\text { Azadirachta indica A. } \\
\text { Juss. GMM008 }\end{array}$ & Neem & $\begin{array}{l}\text { Leaves, } \\
\text { Seeds }\end{array}$ & Tree & Cultivated & $\begin{array}{l}\text { Fresh apical leaves or } \\
\text { stem are pound and } \\
\text { mixed with cold water } \\
\text { and the filtrate drunk, } \\
\text { three tablespoons for } \\
\text { adults and two for } \\
\text { children below five } \\
\text { years }\end{array}$ & 29 & 10.6 & $\begin{array}{l}\text { Ethanol extract of leaves in } \\
\text { hot water showed anti- } \\
\text { plasmodial activity against } \\
\text { the Chloroquine sensitive, } \\
\text { D6 }\left(\mathrm{IC}_{50}=17.9 \mu \mathrm{g} / \mathrm{ml}\right) \text { and } \\
\text { Chloroquine resistant, W2 } \\
\left(\mathrm{IC} \mathrm{C}_{50}=43.7 \mu \mathrm{g} / \mathrm{ml}\right)(\text { Biswas et } \\
\text { al. } 2002, \mathrm{Nanyingi} \text { et al. } \\
2010)\end{array}$ & $\begin{array}{l}\text { More than } 100 \\
\text { compounds have } \\
\text { been isolated } \\
\text { including } \\
\text { isoprenoids, } \\
\text { terpenoids and } \\
\text { gedunin (Biswas et } \\
\text { al. 2002, Nanyingi } \\
\text { et al. 2010) }\end{array}$ \\
\hline
\end{tabular}


Ethnobotany Research and Applications

\begin{tabular}{|c|c|c|c|c|c|c|c|c|c|}
\hline \multicolumn{10}{|l|}{ MORINGACEAE } \\
\hline $\begin{array}{l}\text { Moringa oleifera Lam. } \\
\text { GMM017 }\end{array}$ & Moringa & Leaves & Tree & Cultivated & $\begin{array}{l}\text { Chew the leaves seven } \\
\text { times a day }\end{array}$ & 9 & 3.3 & $\begin{array}{l}\text { Methanol extract of leaves in } \\
\text { hot water: } 9.8 \text { (chloroquine } \\
\text { sensitive, D6); not detected } \\
\text { (Chloroquine resistant, W2) } \\
\text { (Muthaura et al. 2015) }\end{array}$ & $\begin{array}{l}\text { Flavonols } \\
\text { (Muthaura et al. } \\
\text { 2015) }\end{array}$ \\
\hline \multicolumn{10}{|l|}{ MYRTACEAE } \\
\hline $\begin{array}{l}\text { Callistemon citrinus } \\
\text { (Curt.) Stapf GMM003 }\end{array}$ & $\begin{array}{l}\text { Mwambula } \\
\text { butonya }\end{array}$ & $\begin{array}{l}\text { Leaves, } \\
\text { Bark, } \\
\text { Fruits }\end{array}$ & Tree & Wild & $\begin{array}{l}\text { Chew fresh leave, } 10 \\
\text { leaves five times a day } \\
\text { or boil fresh leaves or } \\
\text { bark and drink the } \\
\text { filtrate, a quarter cup } \\
\text { three times a day }\end{array}$ & 80 & 29.3 & No record & \\
\hline $\begin{array}{l}\text { Eucalyptus globulus L. } \\
\text { GMM006 }\end{array}$ & Kalituunsi & Leaves & Tree & Cultivated & $\begin{array}{l}\text { Boil leaves or bark in } \\
\text { water for } 30 \text { minutes, } \\
\text { leave to cool, drink } \\
\text { filtrate ( } 3 \text { tablespoons } \\
\text { for adults or one } \\
\text { tablespoon for children } \\
<6 \text { years) or simply } \\
\text { chew fresh leaves }\end{array}$ & 42 & 15.4 & No record & \\
\hline $\begin{array}{l}\text { Psidium guajava L. } \\
\text { GMM013 }\end{array}$ & Mupera & Leaves & Tree & Cultivated & $\begin{array}{l}\text { Boil leaves for } 30 \\
\text { minutes and drink the } \\
\text { filtrate, two } \\
\text { tablespoons (adults) or } \\
\text { one tablespoon } \\
\text { (children) }\end{array}$ & 16 & 5.9 & $\begin{array}{l}\text { Hot water extract of stem } \\
\text { bark: } 10-20 \text { (chloroquine } \\
\text { sensitive D10) (Pillay et al. } \\
\text { 2008) }\end{array}$ & $\begin{array}{l}\text { Phenolics, } \\
\text { flavonoids, } \\
\text { catenoids, } \\
\text { terpenoids (Pillay et } \\
\text { al. 2008) }\end{array}$ \\
\hline $\begin{array}{l}\text { Syzygium guineense } \\
\text { (Wild.) DC. GMM031 }\end{array}$ & Muziru & Leaves & Tree & Wild & $\begin{array}{l}\text { Decoction and drink, a } \\
\text { whole cup twice a day }\end{array}$ & 3 & 1.1 & $\begin{array}{l}\text { Crude ethanol extract of } \\
\text { leaves in hot water chemo- } \\
\text { suppressed } P . b e r g h e i \text { by } \\
49.09 \% \text { at } 400 \mathrm{mg} / \mathrm{kg} \\
\text { (Tadesse \& Wubneh, 2017) }\end{array}$ & No record \\
\hline \multicolumn{10}{|l|}{ OXALIDACEAE } \\
\hline $\begin{array}{l}\text { Oxalis corniculata L. } \\
\text { GMM024 }\end{array}$ & Kanunu & Leaves & Herb & Wild & $\begin{array}{l}\text { Boil 6-10 leaves in } 4 \\
\text { litres of water for } 1 \\
\text { hour and drink half a } \\
\text { cup of the filtrate three } \\
\text { times a day }\end{array}$ & 5 & 1.8 & No record & \\
\hline \multicolumn{10}{|l|}{ RUBIACEAE } \\
\hline $\begin{array}{l}\text { Coffea canephora } \\
\text { Froehner GMM022 }\end{array}$ & Mwanyi & Leaves & Shrub & Cultivated & $\begin{array}{l}\text { Vaporization and } \\
\text { intranasal inhaling for } \\
\text { leaves or boil the } \\
\text { leaves for } 20 \text { minutes, } \\
\text { leave to cool and drink }\end{array}$ & 6 & 2.2 & No record & \\
\hline
\end{tabular}


Ethnobotany Research and Applications

\begin{tabular}{|c|c|c|c|c|c|c|c|c|c|}
\hline & & & & & $\begin{array}{l}\text { the filtrate, three table } \\
\text { spoons three times }\end{array}$ & & & & \\
\hline \multicolumn{10}{|l|}{ RUTACEAE } \\
\hline $\begin{array}{l}\text { Citrus limon (L.) } \\
\text { Burm.f. GMM010 }\end{array}$ & Niimu & $\begin{array}{l}\text { Leaves, } \\
\text { Fruit, } \\
\text { Seeds }\end{array}$ & Tree & Wild & $\begin{array}{l}\text { Infusion, squeeze juice } \\
\text { of fruit, or crush dried } \\
\text { seeds, add hot water } \\
\text { and drink without sugar } \\
\text { (one cup three times). } \\
\text { Alternatively, chew six } \\
\text { leaves for as many } \\
\text { times as possible }\end{array}$ & 18 & 6.6 & No record & \\
\hline Citrus sp. GMM034 & $\begin{array}{l}\text { Akalimu } \\
\text { akatomo }\end{array}$ & Leaves & Tree & Cultivated & $\begin{array}{l}\text { Either chew fresh } \\
\text { leaves or squeeze } \\
\text { juice out of the fruit and } \\
\text { drink (at least two table } \\
\text { spoons three times). } \\
\text { Dry leaves and seeds } \\
\text { and pound crush to } \\
\text { obtain powder; add hot } \\
\text { water and drink without } \\
\text { adding sugar (at least } \\
\text { one cup three times) }\end{array}$ & 2 & 0.7 & No record & \\
\hline \multicolumn{10}{|l|}{ SOLANACEAE } \\
\hline $\begin{array}{l}\text { Solanum aethiopicum } \\
\text { GMM023 }\end{array}$ & Ndagi & Fruit & Herb & Cultivated & $\begin{array}{l}\text { Chew the fruit and } \\
\text { swallow several times } \\
\text { as you can }\end{array}$ & 6 & 2.2 & No record & \\
\hline $\begin{array}{l}\text { Solanum anguivii Lam. } \\
\text { GMM030 }\end{array}$ & Katunkuma & Fruit & Herb & Wild & $\begin{array}{l}\text { Chew the fruit and } \\
\text { swallow several times } \\
\text { as you can }\end{array}$ & 3 & 1.1 & No record & \\
\hline $\begin{array}{l}\text { Capscicum frutescens } \\
\text { L. GMM037 }\end{array}$ & Kamulali & $\begin{array}{l}\text { Fruit, } \\
\text { Seeds }\end{array}$ & Herb & Cultivated & $\begin{array}{l}\text { Swallowing the } \\
\text { seeds/fruit; eat in food } \\
\text { or pound, add water } \\
\text { and drink several times } \\
\text { a day }\end{array}$ & 1 & 0.4 & No record & \\
\hline \multicolumn{10}{|l|}{ VERBENACEAE } \\
\hline $\begin{array}{l}\text { Lantana camara L. } \\
\text { GMM018 }\end{array}$ & Kappanga & Leaves & Shrub & Wild & $\begin{array}{l}\text { Boil fresh leaves in } \\
\text { water until vapour is } \\
\text { formed. Remove } \\
\text { saucepan from heat } \\
\text { when still covered and } \\
\text { expose the nose to the } \\
\text { vapour (intranasal } \\
\text { inhaling), twice a day }\end{array}$ & 8 & 2.9 & $\begin{array}{l}\text { The dichloromethane and } \\
\text { methanolic extracts of } \\
\text { reported to exhibit invitro } \\
\text { antimalarial activity against } \\
\text { chloroquine sensitive, 3D7 } \\
\text { (IC } C_{50}=5.7 \mu \mathrm{g} / \mathrm{ml} \text { ) and } \\
\text { chloroquine resistant, W2) } \\
\text { strains of } P \text {. falciparum } \\
\left(\mathrm{IC} \mathrm{C}_{50}=14.1 \mu \mathrm{g} / \mathrm{ml} \text { ) (Jonville }\right. \\
\text { et al. 2008). }\end{array}$ & $\begin{array}{l}\text { Ssesquiterpenes, } \\
\text { triterpenes, } \\
\text { flavonoids } \\
\text { (Stangeland et al. } \\
\text { 2011) }\end{array}$ \\
\hline
\end{tabular}


Ethnobotany Research and Applications

\begin{tabular}{|c|c|c|c|c|c|c|c|c|c|}
\hline $\begin{array}{l}\text { Lantana trifolia L. } \\
\text { GMM020 }\end{array}$ & $\begin{array}{l}\text { Kasekera } \\
\text { nyonyi/Kayukiy } \\
\text { uki }\end{array}$ & Leaves & Shrub & Wild & Infusion and inhaling & 6 & 2.2 & $\begin{array}{l}\text { Petroleum ether extract in } \\
\text { hot water effective against } \\
\text { wild strains of } P \text {. falciparum } \\
\left({ }^{-1} C_{50}=13.2 \mu \mathrm{gml}^{-1}\right) \text {; methanol } \\
\text { extract in hot water: }>50 \\
\mu \mathrm{gml}^{-1} \text { (Katuura et al. } 2007 \text { ) }\end{array}$ & $\begin{array}{l}\text { Steroids, } \\
\text { terpenoids, } \\
\text { alkaloids, saponins } \\
\text { (Katuura et al. } \\
\text { 2007) }\end{array}$ \\
\hline \multicolumn{10}{|l|}{ VITACEAE } \\
\hline $\begin{array}{l}\text { Cyphostemma } \\
\text { adenocaule (A. Rich.) } \\
\text { Willd. \& Drumm. } \\
\text { GMM005 }\end{array}$ & Bbombo & $\begin{array}{l}\text { Leaves, } \\
\text { Seeds }\end{array}$ & $\begin{array}{l}\text { Herbaceous } \\
\text { climber }\end{array}$ & Wild & $\begin{array}{l}\text { Squeeze, add water } \\
\text { and drink, two } \\
\text { tablespoons (for those } \\
>10 \text { years old) or one } \\
\text { tablespoon }(6-10 \\
\text { years) three times }\end{array}$ & 44 & 16.1 & No record & \\
\hline \multicolumn{10}{|l|}{ ZINGIBERACEAE } \\
\hline $\begin{array}{l}\text { Zinger officinale L. } \\
\text { GMM027 }\end{array}$ & Ntangawuzi & $\begin{array}{l}\text { Rhizom } \\
\text { es }\end{array}$ & Herb & Cultivated & $\begin{array}{l}\text { Crush, add hot water } \\
\text { and drink the solution, } \\
\text { half a cup three times a } \\
\text { day or chew the stem } \\
\text { three times a day }\end{array}$ & 4 & 1.5 & No record & \\
\hline
\end{tabular}




\section{Declarations}

List of abbreviations: Not applicable. Ethical approval and consent to participate: This study was approved by the Gulu University Research Ethics Committee (GUREC-022-19). Permission to conduct this study was later granted by the local council chairpersons of respective villages. Written informed consent and assent were obtained from the adult participants and persons under the age of 18 , respectively.

Consent for publication: Not applicable.

Conflict of interests: The authors declare that they have no conflict of interests.

Funding: This research work did not receive any specific grant from funding agencies in the public, commercial, or not-for-profit sectors.

Authors' contributions: GMM, KB, KR and $\mathrm{CO}$ participated in designing of the study; KB and $\mathrm{HOO}$ participated in the collection of field data and identification of plant samples. GMM, RO and FA analysed the data and wrote the initial draft of the manuscript. All the authors participated in writing and giving feedback on the manuscript and approved the final version of the manuscript.

\section{Acknowledgements}

We are grateful to the local council authorities in Budondo for allowing us to collect indigenous knowledge of plants used to treat malaria. The authors also thank the participants for sharing their valuable information.

\section{Literature cited}

Adia MM, Emami SN, Byamukama R, Faye I, BorgKarlson AK. 2016. Antiplasmodial activity and phytochemical analysis of extracts from selected Ugandan medicinal plants. Journal of Ethnopharmacology 186: 14-9.

Alemayehu G, Abegaz B, Snatzke G, Duddeck H. 1989. Quinones of Senna didymobotrya. Bulletin of the Chemical Society of Ethiopia 3: 1.

Anywar G, van't Klooster CIEA, Byamukama R, Willcox M, Nalumansi PA, de Jong J, Rwaburindori P, Kiremire BT. 2016. Medicinal plants used in the treatment and prevention of malaria in Cegere SubCounty, Northern Uganda. Ethnobotany Research and Applications 14: 505-516.

Barreto JC, Trevisan MT, Hull WE, Erben G, De Brito ES, Pfundstein B, Würtele G, Spiegelhalder B, Owen RW. 2008. Characterization and quantitation of polyphenolic compounds in bark, kernel, leaves, and peel of mango (Mangifera indica L.). Journal of Agricultural and Food Chemistry 56: 5599-610.

Biswas K, Chattopadhyay I, Banerjee RK, Bandyopadhyay U. 2002. Biological activities and medicinal properties of neem (Azadirachta indica). Current Science-Bangalore. 82: 1336-45.

Canini A, Alesiani D, D'Arcangelo G, Tagliatesta P. 2007. Gas chromatography-mass spectrometry analysis of phenolic compounds from Carica papaya L. leaf. Journal of Food Composition and Analysis 20: 584-90.

Erasto P, Grierson DS, Afolayan AJ. Bioactive sesquiterpene lactones from the leaves of Vernonia amygdalina. 2006. Journal of Ethnopharmacology 106: 117-20.

Jinja District Local Government. Five-year district development plan 2015/16-2019/20.

Jisaka M, Ohigashi H, Takagaki T, Nozaki H, Tada T, Hirota M, Irie R, Huffman MA, Nishida T, Kaji M, Koshimizu K. 1992. Bitter steroid glucosides, vernoniosides $\mathrm{A} 1, \mathrm{~A} 2$, and $\mathrm{A} 3$, and related $\mathrm{B} 1$ from a possible medicinal plant, Vernonia amygdalina, used by wild chimpanzees. Tetrahedron 48: 625-32.

Jonville MC, Kodja H, Humeau L, Fournel J, De Mol P, Cao M, Angenot L, Frederich M. 2008. Screening of medicinal plants from Reunion Island for antimalarial and cytotoxic activity. Journal of Ethnopharmacology 120: 382-6.

Kumar S, Saini A, Gut J, Rosenthal PJ, Raj R, Kumar V. 2017. 4-Aminoquinoline-chalcone/-Nacetylpyrazoline conjugates: Synthesis and antiplasmodial evaluation. European Journal of Medicinal Chemistry 138: 993-1001.

Kakudidi EK, Bukenya-Ziraba R, Kasenene JM. 2000. The medicinal plants in and around Kibale National Park in western Uganda. A Norwegian Journal of Botany 5: 109-124.

Kamatenesi MM, Acipa A, Oryem-Origa H. 2011. Medicinal plants of Otwal and Ngai Sub Counties in Oyam District, Northern Uganda. Journal of Ethnobiology and Ethnomedicine 7: 7.

Katuura E, Waako P, Ogwal-Okeng J, BukenyaZiraba R. 2007. Traditional treatment of malaria in Mbarara District, western Uganda. African Journal of Ecology 45: 48-51.

Kernan MR, Amarquaye A, Chen JL, Chan J, Sesin DF, Parkinson N, Ye ZJ, Barrett M, Bales C, Stoddart CA, Sloan B. 1998. Antiviral phenylpropanoid glycosides from the medicinal plant Markhamia lutea. Journal of Natural Products 61: 564-70.

Komlaga G, Cojean S, Dickson RA, Beniddir MA, Suyyagh-Albouz S, Mensah ML, Agyare C, Champy P, Loiseau PM. 2016. Antiplasmodial activity of selected medicinal plants used to treat malaria in Ghana. Parasitology Research 115: 3185-95.

Lacroix D, Prado S, Deville A, Krief S, Dumontet V, Kasenene J, Mouray E, Bories C, Bodo B. 2009. Hydroperoxy-cycloartane triterpenoids from the leaves of Markhamia lutea, a plant ingested by wild 
chimpanzees. Phytochemistry 70: 1239-45.

Lacroix D, Prado S, Kamoga D, Kasenene J, Namukobe J, Krief S, Dumontet V, Mouray E, Bodo B, Brunois F. 2011. Antiplasmodial and cytotoxic activities of medicinal plants traditionally used in the village of Kiohima, Uganda. Journal of Ethnopharmacology 133: 850-5.

Melariri P, Campbell W, Etusim P, Smith P. 2011. Antiplasmodial properties and bioassay-guided fractionation of ethyl acetate extracts from Carica papaya leaves. Journal of parasitology research 2011. doi:10.1155/2011/104954.

Mesfin A, Giday M, Animut A, Teklehaymanot T. 2012. Ethnobotanical study of antimalarial plants in Shinile District, Somali Region, Ethiopia, and in vivo evaluation of selected ones against Plasmodium berghei. Journal of Ethnopharmacology 139: 221227.

Ministry of Health $(\mathrm{MOH})$, Uganda. 2016. Severe malaria case management in Uganda: a rapid assessment of management of severe malaria at health centres in Jinja district (Acessed 15/6/2019).

Muregi FW, Chhabra SC, Njagi EN, Lang'atThoruwa CC, Njue WM, Orago AS, Omar SA, Ndiege 1O. 2003. In vitro antiplasmodial activity of some plants used in Kisii, Kenya against malaria and their chloroquine potentiation effects. Journal of Ethnopharmacology 84: 235-9.

Muregi FW, Ishih A, Suzuki T, Kino H, Amano T, Mkoji GM, Miyase T, Terada M. 2007. In Vivo antimalarial activity of aqueous extracts from Kenyan medicinal plants and their Chloroquine (CQ) potentiation effects against a blood-induced CQresistant rodent parasite in mice. Phytotherapy Research: An International Journal Devoted to Pharmacological and Toxicological Evaluation of Natural Product Derivatives 21: 337-43.

Muganga R, Angenot L, Tits M, Frederich M. 2010. Antiplasmodial and cytotoxic activities of Rwandan medicinal plants used in the treatment of malaria. Journal of Ethnopharmacology 128: 52-7.

Mukungu N, Abuga K, Okalebo F, Ingwela R, Mwangi J. 2016. Medicinal plants used for management of malaria among the Luhya community of Kakamega East sub-County, Kenya. Journal of Ethnopharmacology 194: 98-107.

Murugan K, Aarthi N, Kovendan K, Panneerselvam C, Chandramohan B, Kumar PM, Amerasan D, Paulpandi M, Chandirasekar R, Dinesh D, Suresh U. 2015. Mosquitocidal and antiplasmodial activity of Senna occidentalis (Cassieae) and Ocimum basilicum (Lamiaceae) from Maruthamalai hills against Anopheles stephensi and Plasmodium falciparum. Parasitology Research 114: 3657-64.

Muthaura CN, Keriko JM, Mutai C, Yenesew A, Gathirwa JW, Irungu BN, Nyangacha R, Mungai GM,
Derese S. 2015. Antiplasmodial potential of traditional antimalarial phytotherapy remedies used by the Kwale community of the Kenyan Coast. Journal of Ethnopharmacology 170: 148-57.

Namukobe J, Kasenene JM, Kiremire BT, Byamukama R, Kamatenesi-Mugisha M, Krief S, Dumontet V, Kabasa JD. 2011. Traditional plants used for medicinal purposes by local communities around the Northern sector of Kibale National Park, Uganda. Journal of Ethnopharmacology 136: 236245.

Nanyingi MO, Kipsengeret KB, Wagate CG, Langat BK, Asaava LL, Midiwo JO. 2010. In vitro and in vivo antiplasmodial activity of Kenyan medicinal plants. Ethnic Groups 16:17.

Nergard CS, Diallo D, Michaelsen TE, Malterud KE, Kiyohara H, Matsumoto T, Yamada H, Paulsen BS. 2004. Isolation, partial characterisation and immunomodulating activities of polysaccharides from Vernonia kotschyana Sch. Bip. ex Walp. Journal of Ethnopharmacology 91: 141-52.

Ocvirk S, Kistler M, Khan S, Talukder SH, Hauner H. 2013. Traditional medicinal plants used for the treatment of diabetes in rural and urban areas of Dhaka, Bangladesh-an ethnobotanical survey. Journal of Ethnobiology Ethnomedicine 9: 43.

Okello D, Kang Y. 2019. Exploring Antimalarial Herbal Plants across Communities in Uganda Based on Electronic Data. Evidence-Based Complementary and Alternative Medicine 2019. https://doi.org/10.1155/2019/3057180

Okoli CO, Akah PA, Nwafor SV, Anisiobi Al, Ibegbunam IN, Erojikwe O. 2007. Anti-inflammatory activity of hexane leaf extract of Aspilia africana CD Adams. Journal of Ethnopharmacology 109: 219-25.

Omoregie ES, Pal A, Sisodia B. 2011. In vitro antimalarial and cytotoxic activities of leaf extracts of Vernonia amygdalina (Del.). Nigerian Journal of Basic and Applied Sciences 19: 121-126.

Olorunnisola OS, Adetutu A, Balogun EA, Afolayan AJ. 2013. Ethnobotanical survey of medicinal plants used in the treatment of malarial in Ogbomoso, Southwest Nigeria. Journal of Ethnopharmacology 150: 71-78.

Oreagba A, Onajole AT, Olayemi SO, Mabadeje AF. 2004. Knowledge of malaria amongst caregivers of young children in rural and urban communities in Southwest Nigeria. Tropical Journal of Pharmaceutical Research 3: 299-304.

Oryem-Origa H, Katende AB, Kakudidi EKZ. 2003. Some medicinal plants in Mukono district. Uganda Journal 49: 56-65.

Pierre S, Alex NN, Jean M. 2011. Medicinal plants used in traditional treatment of malaria in Cameroon. Journal of Ecology and the Natural Environment 3: 104-117. 
Pillay P, Maharaj VJ, Smith PJ. 2008. Investigating South African plants as a source of new antimalarial drugs. Journal of Ethnopharmacology 119: 438-54.

Sendagire H, Kaddumukasa M, Ndagire D, Aguttu C, Nassejje M, Pettersson M, Swedberg G, Kironde F. 2005. Rapid increase in resistance of Plasmodium falciparum to chloroquine-Fansidar in Uganda and the potential of amodiaquine-Fansidar as a better alternative. Acta Tropica 95: 172-182.

Simbo DJ. 2010. An ethnobotanical survey of medicinal plants in Babungo, Northwest Region, Cameroon. Journal of Ethnobiology and Ethnomedicine 6: 8.

Shi LS, Kuo PC, Tsai YL, Damu AG, Wu TS. 2004. The alkaloids and other constituents from the root and stem of Aristolochia elegans. Bioorganic and Medicinal Chemistry 12: 439-46.

Sokal RR, Rholf G: Biometry. 1995, New York: Freeman and Company.

Ssegawa P, Kasenene JM. 2007. Plants for malaria treatment in Southern Uganda: Traditional use, preference and ecological viability. Journal of Ethnobiology 27: 110-132.

Stangeland T, Alele PE, Katuura E, Lye KA. 2011. Plants used to treat malaria in Nyakayojo subcounty, western Uganda. Journal of Ethnopharmacology 137: 154-166.

Tabuti JRS. 2008. Herbal medicines used in the treatment of malaria in Budiope county, Uganda. Journal of Ethnopharmacology 116: 33-42.

Tabuti JRS, Lye KA, Dhillion SS. 2003. Traditional herbal drugs of Bulamogi, Uganda: plants, use and administration. Journal of Ethnopharmacology 88 : 19-44.

Tadesse SA, Wubneh ZB. 2017. Antimalarial activity of Syzygium guineense during early and established Plasmodium infection in rodent models. BMC complementary and Alternative Medicine 17(1):21.

Teng WC, Chan W, Suwanarusk R, Ong A, Ho HK, Russell B, Rénia L, Koh HL. 2019. In vitro antimalarial evaluations and cytotoxicity investigations of Carica papaya leaves and carpaine. Natural Product Communications 14 (1): $1934578 \times 1901400110$.

Teklay A, Abera B, Giday M. 2013. An ethnobotanical study of medicinal plants used in Kilte Awulaelo district, Tigray Region of Ethiopia. Journal of Ethnobiology and Ethnomedicine 9:65.

The Angiosperm Phylogeny Group, Chase MW, Christenhusz MJM, Fay MF, Byng JW, Judd WS, Soltis DE, Mabberley DJ, Sennikov AN, Soltis PS, Stevens PF. 2016. An update of the Angiosperm Phylogeny Group classification for the orders and families of flowering plants: APG IV. Botanical
Journal of the Linnean Society 181: 1-20.

Uganda Bureau of Statistics. National Population and Housing census. 2014. Main Report. https://uganda.unfpa.org/en/publications/nationalpopulation-and-housing-census-2014-0 (accessed 10/11/2018).

Waako PJ, Katuura E, Smith P, Folb P. 2007. East African medicinal plants as a source of lead compounds for the development of new antimalarial drugs. African Journal of Ecology. 45: 102-6.

WHO. 2003. Assessment and monitoring of antimalarial drug efficacy for the treatment of uncomplicated malaria. World Health Organization, Geneva, WHO/HTM/RBM/2003.50.

WHO. 2016. World malaria report. Geneva: World Health Organization.

WHO. 2017. World Malaria Report. Geneva, Switzerland: World Health Organization. Available from: www.who.int/malaria/publications/worldmalaria-report-2017/report/en/

Wu, T.-S., Damu, A.G., Su, C.-R., Kuo, P.-C., 2004. Terpenoids of Aristolochia and their biological activity. Natural Product Reports 21: 594-624.

Zirihi GN, Mambu L, Guédé-Guina F, Bodo B, Grellier P. 2005. In vitro antiplasmodial activity and cytotoxicity of 33 West African plants used for treatment of malaria. Journal of Ethnopharmacology 98: 281- 